\title{
PENGARUH STRATEGI PEMBELAJARAN MNEMONIC TERHADAP HASIL BELAJAR SISWA PADA MATA PELAJARAN EKONOMI DI SMA NEGERI 9 PALEMBANG TAHUN PELAJARAN 2012/2013
}

\author{
Oleh: Kurniati \\ (PT. MARS LESTARI) \\ kurniati678@yahoo.com
}

\begin{abstract}
Abstrak-Strategi pembelajaran mnemonic adalah suatu teknik yang memudahkan penyimpanan, penyandian, dan pengingatan terhadap informasi dalam memori. Masalah dalam penelitian ini adalah apakah terdapat pengaruh strategi pembelajaran mnemonic terhadap hasil belajar siswa pada mata pelajaran ekonomi di SMA Negeri 9 Palembang. Tujuan dalam penelitian ini untuk mengetahui pengaruh strategi pembelajaran mnemonic terhadap hasil belajar siswa pada mata pelajaran ekonomi di SMA Negeri 9 Palembang. Variabel dalam penelitian ini yaitu penerapan strategi pembelajaran mnemonic sebagai variabel bebas $(X)$ dan hasil belajar siswa pada mata pelajaran ekonomi sebagai variabel terikat ( $Y$ ). Teknik pengambilan sampel menggunakan teknik simple random sampling. Teknik pengumpulan data yang digunakan dokumentasi, wawancara dan tes. Teknik analisis data menggunakan analisis regresi linier sederhana dengan pengujian hipotesis uji " $t$ " pada taraf 95\% ( $\alpha$ 0,05). Berdasarkan hasil pembahasan, diketahui dari hasil tes bahwa kelas eksperimen memperoleh nilai 85,5 lebih besar dari kelas kontrol yaitu 78,125. Berdasarkan persamaan regresi $\hat{Y}=78,125+7,375=85,5$ hasil pengujian hipotesis melalui perhitungan uji diperoleh $t_{\text {hitung }}=9,41>t_{\text {tabel }}=1,994$, maka $H_{0}$ ditolak dan $H_{a}$ diterima. Berarti ada Pengaruh penerapan strategi pembelajaran mnemonic terhadap hasil belajar siswa pada pengujian menunjukkan besar pengaruh sebesar 53,14\%, sedangkan selebihnya 46,86\% dipengaruhi oleh faktor lain.
\end{abstract}

Kata Kunci: Strategi, Pembelajaran, Mnemonic

\begin{abstract}
Mnemonic learning strategies are a technique that facilitates storage, encoding, and remembering information in memory. The problem in this study is whether there is an influence of the mnemonic learning strategy on student learning outcomes on economic subjects at Palembang State High School 9. The purpose of this study was to determine the effect of mnemonic learning strategies on student learning outcomes on economic subjects at Palembang State High School 9. The variables in this study are the application of mnemonic learning strategies as independent variables $(X)$ and student learning outcomes on economic subjects as the dependent variable (). The sampling technique uses simple random sampling technique. Data collection techniques used were documentation, interviews and tests. The data analysis technique uses simple linear regression analysis by testing the hypothesis test " $t$ " at the level of $95 \%$ ( $\alpha$ 0.05). Based on the results of the discussion, it is known from the results of the
\end{abstract}


test that the experimental class obtained a value of 85.5 greater than the control class namely 78.125. Based on the regression equation $\hat{Y}=78.125+7.375=$ 85.5 the results of testing the hypothesis through test calculations obtained t count $=9.41>t$ table $=1.994$, then $\mathrm{HO}$ is rejected and Ha is accepted. It means that there is an effect of the application of the mnemonic learning strategy on student learning outcomes in the test showing the influence of $53.14 \%$, while the remaining $46.86 \%$ is influenced by other factors.

Keywords: Strategy, Mnemonic, Learning

\section{PENDAHULUAN}

Pendidikan adalah usaha sadar untuk menyiapkan siswa agar dapat berperan aktif dalam hidupnya sekarang dan yang akan datang. Pendidikan memiliki peranan yang penting dalam pembangunan yaitu mempersiapkan sumber daya manusia yang berkualitas. Hasil akhir suatu proses pendidikan adalah terbentuknya seseorang yang mampu berdiri sendiri, bekerja, dan tak pernah berhenti belajar dan mengembangkan apa yang diperolehnya.

Guru sebagai seseorang yang memegang peranan penting dalam kegiatan pembelajaran harus berupaya untuk mengelola proses pembelajaran seoptimal mungkin, sehingga peserta didik memperoleh hasil yang optimal. Kualitas guru dari segi proses dikatakan berhasil apabila melibatkan sebagian besar peserta didik secara aktif baik fisik, mental maupun sosial dalam proses pembelajaran. Guru harus membantu dalam perkembangan peserta didik untuk dapat menerima dan memahami ilmu pengetahuan.
Seorang pendidik setiap kali mengajar berusaha mengkomunikasikan atau menyampaikan dengan metode yang sesuai agar pokok bahasan yang dipilihnya dapat dikuasai menjadi milik siswa dan menyimpannya dalam memori dalam jangka waktu lama.

Dalam mitologi Yunani, Mnemosyne (yang merupakan asal kata mnemonic) adalah ibu dari sembilan muse (semacam tokoh pujangga) dalam bidang kesenian dan ilmu pengetahuan. Memori dianggap sebagai keterampilan mental tertua dan yang paling dikagumi, memori dianggap sebagai induk dari segala keterampilan lain. Diyakini bahwa jika kita tidak memiliki memori, kita tidak akan pernah memiliki ilmu pengetahuan, kesenian, maupun logika. (Solso dan Maclin, 2007:226).

"Mnemonic adalah suatu teknik yang memudahkan penyimpanan, atau, penyandian, dan pengingatan (recall) terhadap informasi dalam memori". (Solso dan Maclin, 2007:237). Jadi, mnemonic adalah suatu pendekatan 
dalam belajar, dimana siswa berinteraksi dengan mengingat kembali.

Berdasarkan informasi yang di dapat peneliti dari guru mata pelajaran ekonomi di SMA Negeri 9 Palembang bahwa metode yang sering digunakan dalam kegiatan belajar mengajar adalah metode konvensional atau ceramah. Penggunaan metode ceramah belum mampu melibatkan setiap siswa ke dalam kegiatan pembelajaran secara aktif, kreatif, efektif, dan menyenangkan dalam proses belajar mengajar. Hanya siswa tertentu saja yang terlibat dalam proses belajar mengajar, hal itulah yang menyebabkan masih ada $30 \%$ siswa yang belum mencapai standar Kriteria Ketuntasan Minimum (KKM) yaitu 73 untuk mata pelajaran ekonomi. Strategi pembelajaran mnemonic diharapkan dapat menjadi solusi dalam kegiatan belajar mengajar di sekolah agar siswa lebih bersemangat.

Manfaat penggunaan mnemonic, karena memudahkan mengingat, tentunya juga akan memudahkan belajar. Hambatan belajar akan hilang, ini akan membangkitkan motivasi siswa untuk lebih giat belajar, sehingga akhirnya dapat mencapai hasil belajar yang optimal. (http://www.gurusukses.com/mnemo nic/. diakses 25 April 2012)

"Pembelajaran merupakan upaya pengembangan sumber daya manusia yang harus dilakukan secara terus menerus selama manusia hidup" (Marno dan Idris, 2009:161). Pressley (dalam Aqib dan Rohmanto, 2008:67) menjelaskan bahwa "Strategi belajar mengacu pada perilaku dan proses-proses berpikir yang digunakan oleh siswa dan memengaruhi apa yang dipelajari, termasuk memori dan metakognitif".

Menurut Munthe (2009:55) "Strategi pembelajaran adalah alat atau media, bukan tujuan pembelajaran. Strategi pembelajaran dikatakan tepat jika sesuai dengan kecenderungan kompetensi sebagai totalitas hasil belajar yang akan dikembangkan, yakni apakah lebih bersifat kognitif, afektif, atau psikomotorik".

Berdasarkan pendapatpendapat di atas dapat disimpulkan bahwa strategi pembelajaran adalah cara-cara yang akan di pilih dan digunakan oleh seorang pengajar untuk menyampaikan materi pembelajaran sehingga akan memudahkan peserta didik menerima dan memahami materi pembelajaran, yang pada akhirnya tujuan pembelajaran dapat dikuasainya di akhir kegiatan belajar.

Aqib dan Rohmanto (2008:68) mengemukakan ada 4 jenis strategi belajar yang dapat di pilih dan digunakan pembelajar dalam menyelesaikan tugas-tugas belajar di sekolah, yaitu:

1. Strategi Mengulang atau reherseal strategis, yang terdiri 
dari 2 (dua) jenis, mengulang sederhana dan mengulang kompleks.

2. Strategi Elaborasi, yang sering digunakan dalam pembelajaran yaitu pembuatan catatan, penggunaan analogi, dan metode PQ4R.

3. Strategi Organisasi, terdiri dari pengelompokan ide-ide atau istilah-istilah tersebut menjadi bagian yang lebih kecil. Outlining, mapping, dan mnemonics adalah strategi organisasi yang umum digunakan.

4. Strategi Metakognitif, berhubungan dengan bagaimana cara berpikir siswa dan mendapatkan pengetahuan.

Sebagian besar dari kita dapat dengan mudah mengingat lagu kesayangan, mengingat acara-acara televisi dan hal yang menarik pikiran kita, namun pada hal tertentu kita cukup sulit mengingat dan lemah menyimpannya yaitu adalah masalah pelajaran padahal baru lima atau sepuluh menit kita memperolehnya tetapi sudah lupa atau tidak jelas dalam mengkopi kedalam memori.

“Mnemonic (di baca ne-mahn'ick) adalah suatu teknik yang meningkatkan penyimpanan dan pengambilan informasi dalam memori". (Solso dan Maclin, 2007:226). Menurut Aqib dan Rohmanto (2008:70) "Mnemonic adalah teknik-teknik atau strategi untuk membantu ingatan dengan membentuk asosiasi yang secara alamiah tidak ada".

Berdasarkan pendapatpendapat di atas dapat disimpulkan bahwa mnemonic adalah teknik untuk memudahkan mengingat sesuatu dengan cara-cara tertentu.

Santrock

(2010:331)

mengemukakan bahwa: Strategi mengajar untuk membantu murid meningkatkan memori mereka antara lain:

1. Motivasi anak untuk mengingat materi dengan pemahaman, bukan dengan mengingatnya begitu saja. Anak akan mengingat informasi dengan baik dalam jangka panjang jika mereka memahami Informasi, bukan sekedar mengingatnya tanpa pemahaman. Jadi, untuk sebagian besar informasi, dorong murid untuk memahaminya, memberinya makna, mengelaborasinya, dan mempersonalisasikannya. Beri anak konsep dan ide untuk di ingat dan kemudian tanyakan kepada mereka bagaimana mereka dapat mengaitkan konsep dan ide itu dengan pengalaman personal dan makna personalnya. Beri mereka latihan untuk mengelaborasi konsep agar mereka bisa memproses informasi secara lebih mendalam.

2. Bantu murid menata apa yang mereka masukkan dalam memori. Anak-anak akan mengingat informasi dengan lebih baik jika 
mereka menatanya secara hierarkis. Beri mereka latihan menata dan mengolah materi yang membutuhkan penstrukturan.

3. Ajari anak strategi mnemonic. Mnemonic (atau cara menghafal atau metode "jembatan keledai") adalah bantuan memori untuk mengingat informasi. Mnemonic juga dapat menggunakan imajinasi dan kata. Berikut ini beberapa tipe mnemonic antara lain:

- Metode Loci, dalam metode loci anak menyusun imaji/citra dari suatu item yang akan di ingat dan membayangkannya dia akan menyimpannya dalam lokasi yang dikenali. Kamar di rumah atau toko atau jalan adalah lokasi umum yang biasa di pakai dalam strategi memori ini. Misalnya, jika anak harus mengingat sederetan konsep, mereka bisa secara mental (membayangkannya)

meletakkanya dalam ruangan di rumah mereka, seperti di sebelah pintu masuk, ruang keluarga, ruang makan, dapur dan sebagainya. Saat mereka perlu mengambil kembali informasi itu, mereka dapat membayangkan rumahnya, lalu membayangkan dirinya berjalan dikamar, lalu mengambil kembali konsep belajar tersebut.
- Rima.

Contohnya, "Mejikuhibiniu" untuk mengingat warna pelangi (merah, jingga, kuning, hijau, biru, nila, ungu).

- Akronim, strategi ini adalah menciptakan kata dari huruf pertama item yang akan diingat. Misalnya, HOMES dapat dipakai sebagai petunjuk untuk mengingat lima Danau Besar: Huron, Ontario, Michigan, Erie, dan Superior.

- Metode kata kunci. Strategi Penghafalan lainnya yang menggunakan imajinasi adalah metode kata kunci, di mana imaji yang hidup dilekatkan pada kata penting. Metode ini telah di pakai untuk mengajari murid cara menguasai informasi baru seperti kosa kata asing, negara dan ibu kota negara.

Teknik mnemonic atau peningkatan daya ingat, memfungsikan otak kanan untuk diaktifkan, karena anak di latih untuk membuat suatu cerita, lagu atau irama serta berimajinasi sehingga seseorang akan mudah mengingat sebuah informasi, catatan, dan lainlain yang sudah dipelajari. Manfaat belajar dan mengajar dengan mengoperasikan strategi mnemonic antara lain:

a. Strategi ini secara otomatis memberi semangat siswa sehingga tertarik, karena anak di 
latih untuk membuat suatu cerita, berimajinasi, irama dan gambar.

b. Dengan menggunakan teknikteknik mnemonic dapat memudahkan siswa dalam mengingat materi pelajaran yang ada.

c. Apabila siswa dapat menggunakan strategi mnemonic dengan efisien, mereka dapat memaksimalkan waktu belajar dan mengejar target lebih mudah.

d. Strategi mnemonic membantu siswa mengingat informasi lebih cepat dan mempertahankannya lebih lama.

Ada tiga unsur dasar yang terlibat dalam proses mengingat kembali secara cepat. Agar setiap pembelajaran informasi baru dapat terpatri dalam ingatan yaitu:

- dikodekan (direkam)

- di rawat atau diperkuat (di simpan)

- di ingat kembali melalui asosiasi

Tiga unsur dasar di atas, yang akan memberikan peluang dalam menguasai pembelajaran yang harus dikuasai dan pembelajaran yang diinginkan dengan memanfaatkan waktu secara efisien. (http://akmalmr.blogspot.com/2011/03/strategi-

belajar-mnemonic.html diakses tanggal 25 April 2012).

Menurut Mulyana (2008:36) "Belajar adalah suatu proses dari dalam yang dikontrol langsung oleh peserta sendiri dan melibatkan dirinya termasuk fungsi intelek, emosi, dan fisik". Sedangkan menurut Blomm, dkk (dalam Aqib dan Rohmanto, 2008:59) "Belajar adalah proses perubahan perilaku akibat interaksi individu dengan lingkungan".

Berdasarkan pendapatpendapat di atas dapat disimpulkan bahwa belajar adalah suatu proses usaha yang dilakukan seseorang untuk memperoleh suatu perubahan pada diri seseorang secara keseluruhan dalam interaksi dengan lingkungannya.

"Hasil Belajar adalah kemampuan-kemampuan yang dimiliki oleh siswa setelah menerima pengalaman belajar yang meliputi aspek kongnitif, efektif, dan psikomotorik". (Sudjana, 2009:22). Sedangkan menurut Hamalik (2010:28) "Hasil belajar yang utama ialah pola tingkah laku yang bulat".

Gayne (dalam Aqib dan Rohmanto, 2008:59) mengklasifikasi hasil belajar menjadi lima kategori yaitu informasi verbal, kemahiran intelektual, strategi kognitif yang termasuk ranah kognitif, sikap dari ranah afektif, dan keterampilan motorik dari ranah psikomotorik".

Berdasarkan pendapatpendapat di atas dapat disimpulkan bahwa hasil belajar adalah kemampuan yang diperoleh seseorang dari suatu sistem pemprosesan berbagai masukan setelah melalui kegiatan belajar.

Menurut Adji, dkk (2007:3) "Ekonomi adalah ilmu yang 
mempelajari tentang penggunaan sumber daya yang terbatas untuk memenuhi kebutuhan manusia yang tidak terbatas". Sedangkan menurut Nash ( 2010:6). "Ilmu ekonomi adalah cabang ilmu sosial yang membahas tentang perilaku manusia atau kelompok masyarakat, setiap usahanya memenuhi kebutuhan yang relatif tak terbatas dengan alat yang biasa digunakan pemuas kebutuhan yang terbatas adanya".

Dari beberapa pendapat di atas maka dapat disimpulkan bahwa ilmu ekonomi itu adalah ilmu yang mempelajari aktivitas manusia dalam memenuhi kebutuhan hidupnya yang tidak terbatas dan untuk mencapai kemakmuran dengan menggunakan sumber daya yang terbatas melalui pilihan-pilihan kegiatan produksi, konsumsi, dan distribusi.

Fungsi mata pelajaran ekonomi adalah mengembangkan kemampuan siswa untuk berekonomi, dengan cara mengenal sebagai kenyataan dan peristiwa ekonomi, memahami konsep dan teori serta berlatih dalam memecahkan masalah ekonomi yang terjadi dalam lingkungan masyarakat.

Tujuan mata pelajaran

ekonomi di Sekolah Menengah Atas adalah:

1. Membekali siswa dengan sejumlah konsep ekonomi untuk memenuhi dan mengerti peristiwa dan masalah ekonomi dalam kehidupan sehari-hari, terutama yang terjadi dilingkungan setingkat individu atau rumah tangga, masyarakat, dan negara.

2. Membekali siswa dengan sejumlah konsep ekonomi yang diperlukan untuk mendalami ilmu ekonomi pada jenjang selanjutnya.

3. Membekali siswa dengan nilainilai serta ekonomi dan memiliki jiwa kewirausahaan.

4. Meningkatkan kemampuan kompetensi dan bekerja sama dalam masyarakat yang majemuk, baik dalam skala nasional maupun skala internasional. (Depdiknas, 2003:2)

Kompetensi dasar pada pokok bahasan APBN dan APBD adalah menjelaskan pengertian, fungsi, tujuan APBN dan APBD.

1) Pengertian $A P B N$ dan $A P B D$

APBN merupakan

kependekan dari Anggaran Pendapatan dan Belanja Negara. APBN adalah rencana keuangan tahunan pemerintah Negara Republik Indonesia yang disetujui oleh DPR (Dewan perwakilan Rakyat). APBN berisi daftar sistematis yang memuat penerimaan dan pengeluaran negara selama 1 tahun (1 januari sampai 31 desember) tahun berjalan.

APBD (Anggaran Pendapatan dan Belanja Daerah) adalah rencana keuangan tahunan daerah yang ditetapkan berdasarkan peraturan daerah tentang Anggaran Pendapatan dan Belanja Daerah.

2) Fungsi APBN dan APBD 
APBN mempunyai fungsi otorisasi, perencanaan, pengawasan, alokasi, distribusi, dan stabilisasi. Semua penerimaan yang menjadi hak dan pengeluaran yang menjadi kewajiban negara dalam suatu tahun anggaran harus dimasukkan dalam APBN. Surplus penerimaan negara dapat digunakan untuk membiayai pengeluaran negara tahun anggaran berikutnya.

APBD yang disusun oleh setiap daerah memiliki fungsi sebagai otorisasi, perencanaan, pengawasan, alokasi, dan distribusi.

3) Tujuan APBN dan APBD

Tujuan APBN adalah sebagai pedoman penerimaan dan pengeluaran negara dalam melaksanakan kegiatan produksi dan kesempatan kerja dalam rangka meningkatkan perekonomian. Sedangkan Tujuan APBD adalah sebagai pedoman penerimaan dan pengeluaran negara dalam rangka pelaksanaan otonomi daerah dan untuk meningkatkan kemakmuran masyarakat.

\section{METODE PENELITIAN}

"Metode penelitian adalah cara yang digunakan oleh peneliti dalam mengumpulkan data penelitiannya" (Arikunto, 2010:203). Adapun metode yang digunakan dalam penelitian ini adalah metode penelitian eksperimen. "Metode penelitian eksperimen merupakan metode penelitian yang digunakan untuk mencari pengaruh treatment (perlakuan) tertentu" (Sugiyono, 2012:11).

\section{HASIL PENELITIAN DAN PEMBAHASAN \\ HASIL PENELITIAN}

Pelaksanaan penelitian dilakukan di SMA Negeri 9 Palembang dilaksanakan selama tiga minggu dengan dua kali pertemuan untuk kegiatan pembelajaran dan pada pertemuan ketiga diadakan tes pada akhir penelitian setelah kegiatan pembelajaran. Sampel dalam penelitian sebanyak 80 orang terdiri dari dua kelas yaitu kelas XI IPS 1 sebagai kelas eksperimen berjumlah 40 orang siswa dan kelas XI IPS 2 sebagai kelas kontrol berjumlah 40 orang siswa. Dalam penelitian ini menggunakan metode pembelajaran mnemonic pada kelas XI IPS 1 (kelas eksperimen) dan dengan metode ceramah dan tanya jawab pada kelas XI IPS 2 (kelas kontrol).

\section{Pelaksanaan Penelitian di Kelas Eksperimen}

Pada kelas eksperimen ini peneliti melakukan proses belajar mengajar dengan menggunakan metode pembelajaran mnemonic pada mata pelajaran ekonomi dengan materi APBN dan APBD di SMA Negeri 9 Palembang kelas XI IPS 1 sebagai kelas yang diberikan perlakuan. Dalam pelaksanaan penelitian ini peneliti mengajari anak strategi mnemonic dengan cara anak 
menyusun imaji/citra dari suatu item yang akan di ingat dan ditransfernya kedalam memori. Peneliti melaksanakan 3 (tiga) kali pertemuan yaitu 2 (dua) kali pertemuan untuk proses pembelajaran dan 1 (satu) kali pertemuan untuk pemberian tes. Berikut rincian kegiatan selama penelitian:

1. Pada pertemuan pertama peneliti mengisi 2 (dua) jam pelajaran di kelas XI IPS 1 Peneliti membuka pelajaran dengan salam, peneliti memperkenalkan diri, dan memberitahukan tujuan kedatangan ke kelas, serta memberikan pengarahan tentang proses pembelajaran yang akan dilaksanakan yaitu tentang metode pembelajaran mnemonic. Peneliti menyampaikan materi tentang pengertian APBN, tujuan dan fungsi APBN, serta prinsip, asas, dan cara penyusunan APBN.

2. Pada pertemuan kedua materi yang diajarkan mengenai pengertian APBD, tujuan dan fungsi APBD, serta cara penyusunan APBD. Kemudian siswa diberikan latihan soal setelah selesai mengerjakan, soal tersebut di bahas bersama.

3. Pertemuan ketiga yang dilakukan pada tanggal 28 September 2012 peneliti memberikan evaluasi melalui tes tertulis berbentuk essay yang berjumlah 5 soal. Soal, kunci jawaban, penskoran, lembar jawaban siswa, dapat di lihat pada lampiran.

\section{Pelaksanaan Penelitian di Kelas Kontrol}

Pada kelas kontrol ini peneliti melakukan proses belajar mengajar dengan menggunakan metode ceramah dan tanya jawab. Proses belajar mengajar yang dilakukan peneliti di kelas kontrol sebanyak 3 kali pertemuan dengan 2 RPP. Untuk RPP pada saat penelitian di kelas kontrol dapat di lihat pada lampiran.

Langkah-langkah pelaksanaan pembelajaran dengan menggunakan metode ceramah dan tanya jawab yang peneliti lakukan di kelas kontrol yaitu pada kelas XI IPS 2 adalah:

1. Pertemuan pertama yang dilakukan pada tanggal 20 September 2012 pada pokok bahasan APBN dan APBD. Guru menjelaskan materi dengan menggunakan metode ceramah dan tanya jawab, dan melalui metode tanya jawab siswa diberi kesempatan untuk bertanya mengenai materi pembelajaran yang belum dipahaminya dan guru memberikan penjelasan tentang materi yang ditanyakan siswa.

2. Pertemuan kedua yang dilakukan pada tanggal 24 September 2012, guru menjelaskan materi sebelumnya kemudian menjelaskan materi 
selanjutnya dengan metode pembelajaran yang sama yaitu ceramah dan tanya jawab.

3. Pertemuan ketiga yang dilakukan pada tanggal 27 September 2012 peneliti memberikan evaluasi melalui tes tertulis berbentuk essay yang berjumlah 5 soal. Soal, kunci jawaban, penskoran, lembar jawaban siswa, dapat di lihat pada lampiran.

\section{Deskripsi Data Tes Hasil Belajar}

Nilai tes pada dasarnya bertujuan untuk mengukur hasil belajar siswa pada akhir kegiatan pembelajaran. Hasil belajar yang di maksud adalah tes hasil belajar yang diberikan guru kepada siswa yang menjadi kelompok eksperimen dan kelompok kontrol. Dalam hal ini kelompok eksperimen adalah kelas yang proses belajar mengajarnya menggunakan metode pembelajaran mnemonic dalam pembelajaran ekonomi dengan materi APBN dan APBD. Sedangkan kelompok kontrol adalah kelas yang proses belajar mengajarnya tidak menggunakan metode pembelajaran mnemonic melainkan menggunakan metode ceramah dan tanya jawab.

Tes diberikan pada kedua kelompok tersebut pada akhir kegiatan pembelajaran dalam penelitian ini. Materi yang dijelaskan pada kedua kelompok tersebut adalah sama yaitu dengan materi APBN dan APBD

\section{Data Nilai Tes Siswa Kelas Eksperimen}

Nilai tes dari hasil penelitian pada kelas eksperimen atau kelas yang mendapatkan pelaksanaan pembelajaran dengan menggunakan metode pembelajaran mnemonic hasil belajar kelas eksperimen siswa yang mendapat nilai baik sekali ada 20 orang dengan persentasenya sebesar $50 \%$, siswa yang mendapat nilai baik ada 14 orang persentasenya $30 \%$, siswa yang mendapat nilai cukup ada 5 orang persentasenya $12,5 \%$, sedangkan siswa yang mendapat nilai rendah hanya 1 orang persentasenya $2,5 \%$. Jadi, dapat disimpulkan bahwa kelas eksperimen rata-rata mendapatkan nilai dengan kategori baik sekali.

\section{Data Nilai Tes Siswa Kelas Kontrol}

Nilai tes penelitian kelas kontrol yang tidak diberi pelaksanaan pembelajaran dengan metode pembelajaran mnemonic hasil belajar kelas kontrol siswa yang mendapat nilai baik sekali ada 6 orang dengan persentasenya $15 \%$, siswa yang mendapat nilai baik ada 20 orang dengan persentasenya $50 \%$, sedangkan untuk siswa yang mendapat nilai cukup ada 14 orang dengan persentasenya $35 \%$. Jadi dapat disimpulkan bahwa kelas kontrol rata-rata mendapatkan nilai dengan kategori baik. 
Perbandingan Data Nilai Tes Siswa Kelas Eksperimen dengan Kelas Kontrol

Dari data di atas dapat diketahui perbandingan data tes siswa kelas eksperimen dan kelas kontrol bahwa perbandingan hasil belajar antara siswa kelas eksperimen dengan siswa kelas kontrol, ternyata hasil belajar siswa pada kelas eksperimen yang menggunakan metode pembelajaran mnemonic lebih tinggi dari pada hasil belajar pada kelas kontrol.

\section{Analisis Data Hasil Tes}

Berdasarkan data yang diperoleh maka dapat dilakukan perhitungan analisis regresi linier sederhana. Langkah-langkah perhitungan analisis regresi sederhana yaitu:

\section{Uji Regresi Linier Sederhana}

Analisis data statistik dalam penelitian ini digunakan untuk melihat pengaruh dari penggunaan strategi pembelajaran mnemonic terhadap hasil belajar.

Setelah data hasil tes terkumpul, kemudian data tersebut diolah sehingga dapat dianalisis. Berdasarkan tabel bantu menghitung persamaan regresi yang dapat di lihat pada data lampiran, maka diperoleh data-data sebagai berikut:
$\mathrm{N} \quad=80$
$\sum \mathrm{Y}=6545$
$\sum \mathrm{X}=40$
$\sum Y^{2}=$
548825
$\sum X^{2}=40$
$\sum X Y=3420$

$\overline{\mathrm{X}}=0,5 \quad \widehat{\mathrm{Y}}=81,81$

Dari perhitungan di atas dapat di hitung harga a dan b yaitu:

$$
\begin{gathered}
a=\frac{\left(\sum y_{i}\right)\left(\sum x_{i}^{2}\right)-\left(\sum x_{i}\right)\left(\sum x_{i} y_{i}\right)}{n \sum x_{i}^{2}-\left(\sum x_{i}\right)^{2}} \\
a=\frac{(6545)(40)-(40)(3420)}{80(40)-(40)^{2}} \\
a=\frac{261800-136800}{3200-1600} \\
a=\frac{125000}{1600} a=78,125 \\
b=\frac{n \sum x_{i} y_{i}-\left(\sum x_{i}\right)\left(\sum y_{i}\right)}{n \sum x_{i}^{2}-\left(\sum x_{i}\right)^{2}} \\
b=\frac{80(3420)-(40)(6545)}{80(40)-(40)^{2}} \\
b=\frac{80(3420)-(40)(6545)}{80(40)-(40)^{2}} \\
b=\frac{273600-261800}{3200-1600} \\
b=\frac{11800}{1600} b=7,375 \\
\text { Nilai a hasil perhitungan }
\end{gathered}
$$
tersebut di atas merupakan konstanta regresi sebesar 78,125 dan nilai $b$ sebesar 7,375. Berdasarkan kedua perhitungan tersebut, diperoleh persamaan regresi yaitu:

$\mathrm{Y}=\mathrm{a}+\mathrm{bX}$

$Y=78,125+7,375 X$

Maka dapat di hitung nilai rata-rata hasil belajar dari kelas eksperimen dengan nilai $\mathrm{X}=1$ dan pada kelas kontrol nilai $X=0$, sebagai berikut:

a. Nilai rata-rata hasil belajar kelas eksperimen

$$
\begin{aligned}
\widehat{\mathrm{Y}} & =\mathrm{a}+\mathrm{bX} \\
& =78,125+7,375(1) \\
& =78,125+7,375 \\
& =85,5
\end{aligned}
$$


b. Nilai rata-rata hasil belajar kelas kontrol

$$
\begin{aligned}
\widehat{\mathrm{Y}} & =\mathrm{a}+\mathrm{bX} \\
& =78,125+7,375(0) \\
& =78,125+0=78,125
\end{aligned}
$$

Dengan nilai koefisien regresi (b) yang positif, hal ini menunjukkan bahwa terdapat pengaruh yang positif dari perlakuan metode pembelajaran mnemonic terhadap hasil belajar siswa pada kelas eksperimen sebesar 7,375.

\section{Perhitungan Korelasi Product}

Moment

Untuk mengetahui besarnya pengaruh variabel $\mathrm{X}$ (penerapan metode pembelajaran mnemonic) terhadap variabel Y (hasil belajar siswa) maka peneliti menggunakan rumus korelasi Produt Moment yang perhitungannya sebagai berikut:

$r_{x y}=\frac{\sum x y}{\sqrt{\left\{\sum x^{2}\right\}\left\{\sum \mathrm{y}^{2}\right\}}}$

$r_{x y}=\frac{3420}{\sqrt{(40)(548825)}}$

$r_{x y}=\frac{3420}{\sqrt{21953000}}$

$r_{x y}=\frac{3420}{4685,40} r_{x y}=0,729$

Koefisien korelasi $\left(r_{x y}\right)$ yang diperoleh berdasarkan perhitungan di atas adalah 0,729 dengan kategori tingkat hubungan kuat. Dari nilai koefisien tersebut selanjutnya di hitung koefisien determinasi yang di sebut juga koefisien penentu $(\mathrm{KP})=$ $r^{2} \times 100 \%=(0.729)^{2} \times 100 \%=$
53,14\%. Berarti tingkat interpretasi pengaruh metode pembelajaran mnemonic terhadap hasil belajar siswa sebesar 53,14\%, sedangkan selebihnya $46,86 \%$ dipengaruhi oleh faktor lain.

\section{Pengujian Hipotesis}

Pembuktian hipotesis dengan uji "t" yaitu sebagai berikut:

\section{a. Hipotesis}

$$
\begin{aligned}
\mathrm{H}_{0}=0 ; & \text { Tidak ada } \\
& \text { pengaruh } \\
& \text { penerapan metode } \\
& \text { pembelajaran } \\
& \text { mnemonic } \\
& \text { terhadap hasil } \\
& \text { belajar siswa. } \\
\mathrm{H}_{\mathrm{a}} \neq 0 ; & \text { Ada pengaruh } \\
& \text { penerapan metode } \\
& \text { pembelajaran } \\
& \text { mnemonic } \\
& \text { terhadap hasil } \\
& \text { belajar siswa. }
\end{aligned}
$$

\section{b. Statistik Uji}

Statistik uji yang sesuai adalah statistik " $\mathrm{t}$ " tes melalui regresi linear sederhana.

\section{c. Taraf Kepercayaan}

Taraf kepercayaan yang digunakan adalah $95 \%$ atau $\alpha$ 0,05 .

\section{d. Harga $t_{\text {tabel }}$ Daerah Kritis} Harga $t_{\text {tabel }}$ pada $\alpha 0,05 \mathrm{dk}(\mathrm{n}-$ $\mathrm{k}-1)=\mathrm{dk}(80-1-1)=78=$ 1,994 


\section{e. Kriteria Pengujian}

Terima $\mathrm{H}_{0}$ : bila $\mathrm{t}_{\text {hitung }} \leq \mathrm{t}_{\text {tabel }}$ 1,999 : tolak Ha

Tolak $\mathrm{H}_{0}$ : bila $\mathrm{t}_{\text {hitung }} \geq \mathrm{t}_{\text {tabel }}$ 1,999 : terima $\mathrm{Ha}$

\section{f. Pengujian Hipotesis}

Perhitungan pengujian hipotesis dengan menggunakan uji " $\mathrm{t}$ " dengan langkah-langkah sebagai berikut:

1) Menghitung Standar

\section{Error Dugaan Hasil}

Regresi (Se)

$S e=\frac{\sqrt{\sum y^{2}-b \sum x y}}{n-2}$

$S e=\frac{\sqrt{548825-7,375(3420)}}{80-2}$

$S e=\frac{\sqrt{548825-25222,5}}{78}$

$S e=\frac{\sqrt{523602,5}}{78}$

$S e=\frac{723,60}{78} S e=9,27$

2) Menghitung Standar

Error Koefisien Regresi

(Sb)

$$
\begin{aligned}
& \mathrm{Sb}=\frac{\mathrm{Se}}{\sqrt{\sum x^{2}}}=\frac{9,27}{\sqrt{40}}=\frac{9,27}{6,32} \\
& =1,46
\end{aligned}
$$

3) Menghitung Harga $t_{\text {hitung }}$

$t_{\text {hit }}=\frac{b}{S b}=\frac{7,575}{1,46}=5,051$
4) Menghitung signifikansi koefisien korelasi

$\mathrm{t}=\frac{r \sqrt{n-2}}{\sqrt{1-r^{2}}}$

$\mathrm{t}=\frac{0,729 \sqrt{80-2}}{\sqrt{1-(0,729)^{2}}}$

$\mathrm{t}=\frac{0,729 \sqrt{78}}{\sqrt{1-0,531}}$

$\mathrm{t}=\frac{0,729(8,83)}{\sqrt{0,469}}$

$\mathrm{t}=\frac{6,437}{0,684} \mathrm{t}=9,41$

\section{5) Taraf uji}

Untuk

menguji hipotesis, adapun rumus $\mathrm{dk}$ yang digunakan yaitu $\mathrm{dk}=\mathrm{n}$ $2, \mathrm{dk}=80-2=78$. Karena $\mathrm{di}$ dalam tabel tidak ada nilai 78 maka digunakanlah rumus interpolasi dengan taraf kepercayaan 95\%. Cara menghitung interpolasi pada tabel " $t$ " yaitu:

$\mathrm{C}=\mathrm{C}_{0}+$

$\frac{\left(C_{1}-C_{0}\right)}{\left(B_{1}-B_{0}\right)} \cdot\left(B-B_{0}\right)$

Diketahui:

$\mathrm{B}=78(\mathrm{dk}=\mathrm{n}-2=80-2)$

$\mathrm{B}_{0}=60$

$\mathrm{B}_{1}=120$

$\mathrm{C}_{0}=2,000$

$\mathrm{C}_{1}=1,980$

$\mathrm{C}=\mathrm{C}_{0}+\frac{\left(C_{1}-C_{0}\right)}{\left(B_{1}-B_{0}\right)} \cdot\left(B-B_{0}\right)$ 


$$
\begin{aligned}
& \begin{array}{l}
=2,000+ \\
\frac{(1,980-2,000)}{120-60} \cdot(78-60)
\end{array} \\
& =2,000+\frac{(-0,02)}{60} \cdot 18 \\
& =2,000+(-0,006) \\
& =1,994
\end{aligned}
$$

\section{6) Kesimpulan}

Dari perhitungan uji $t$ di atas diperoleh $\mathrm{t}$ hitung $=9,41>\mathrm{t}$ tabel $=$ 1,994, maka $\mathrm{H}_{0}$ di tolak dan $\mathrm{H}_{\mathrm{a}}$ di terima. Dengan demikian terdapat pengaruh yang positif dari penggunaan strategi pembelajaran mnemonic terhadap hasil belajar siswa pada mata pelajaran ekonomi kelas XI IPS di SMA Negeri 9 Palembang tahun pelajaran 2012/2013.

\section{PEMBAHASAN}

Berdasarkan hasil analisis data tes kedua kelas sebagai sampel yaitu kelas XI IPS 1 (kelas eksperimen) dan kelas XI IPS 2 (kelas kontrol) dalam menyelesaikan soal-soal pada tes pertemuan terakhir maka dari hasil belajar kelas eksperimen memperoleh nilai ratarata 85,5 pada kriteria "baik sekali" dengan distribusi nilai hasil belajar siswa yang mendapat nilai baik sekali ada 20 orang dengan persentasenya sebesar 50\%, siswa yang mendapat nilai baik ada 14 orang persentasenya $30 \%$, siswa yang mendapat nilai cukup ada 5 orang persentasenya $12,5 \%$, sedangkan siswa yang mendapat nilai rendah hanya 1 orang persentasenya $2,5 \%$. Sedangkan pada kelas kontrol diperoleh nilai rata-rata sebesar 78,125 pada kriteria "baik", dengan distribusi nilai hasil belajar siswa yaitu siswa yang mendapat nilai baik sekali ada 6 orang dengan persentasenya $15 \%$, siswa yang mendapat nilai baik ada 20 orang dengan persentasenya $50 \%$, sedangkan untuk siswa yang mendapat nilai cukup ada 14 orang dengan persentasenya $35 \%$.

Dengan demikian dapat disimpulkan bahwa rata-rata belajar siswa cenderung lebih baik pada kelas XI IPS 1 (kelas eksperimen) dibandingkan dengan kelas XI IPS 2 (kelas kontrol), karena kelas eksperimen menerapkan strategi pembelajaran mnemonic yang mampu meningkatkan hasil belajar siswa pada materi yang telah diberikan, sehingga dapat lebih memahami konsep dasar materi pembelajaran. Manfaat penggunaan mnemonic, karena memudahkan mengingat, tentunya juga akan memudahkan belajar. Hambatan belajar akan hilang, ini akan membangkitkan motivasi siswa untuk lebih giat belajar, sehingga akhirnya dapat mencapai hasil belajar yang optimal.

Dari hasil analisis data hasil belajar siswa, dapat di lihat perhitungan regresi linear sederhana yaitu $\hat{Y}=78,125+7,375 \mathrm{X}$, berarti dengan adanya strategi pembelajaran mnemonic yang dilakukan dalam proses pembelajaran maka hasil 
belajar bertambah 7,375 (dengan $X=1$, sehingga pertambahan tersebut adalah 7,375 X $1=7,375)$, maka hasil belajar dengan menggunakan strategi pembelajaran mnemonic adalah $78,12+7,375=85,5$. Dari perhitungan uji $\mathrm{t}$ diperoleh $\mathrm{t}$ hitung $=$ 9,41 $>\mathrm{t}$ tabel $=1,994$, maka $\mathrm{H}_{0}$ di tolak dan $\mathrm{H}_{\mathrm{a}}$ di terima. Dengan demikian terdapat pengaruh yang positif dari penggunaan strategi pembelajaran mnemonic terhadap hasil belajar siswa pada mata pelajaran ekonomi di SMA Negeri 9 Palembang. Setelah di analisis dari data penelitian pada pengajaran yang menggunakan strategi pembelajaran mnemonic pada siswa kelas XI IPS 1 (kelas eksperimen) dan kelas XI IPS 2 (kelas kontrol) yang tidak menggunakan strategi pembelajaran mnemonic di mana variabel bebas $(X)$ dan variabel terikat $(Y)$ didapatkan pada perhitungan koefisien determinasi $\left(\mathrm{r}^{2}\right)$ adalah 0,5314 atau 53,14\%. Berarti terdapat pengaruh metode pembelajaran mnemonic terhadap hasil belajar siswa sebesar 53,14\%, sedangkan selebihnya $46,86 \%$ dipengaruhi oleh faktor lain.

Jadi, pada pengujian dengan uji " $t$ " menunjukkan pengaruh yang positif terhadap hasil belajar siswa dengan menggunakan metode pembelajaran mnemonic pada mata pelajaran ekonomi dalam pokok bahasan APBN dan APBD di SMA Negeri 9 Palembang. Dari data penelitian di atas, didapatkan bahwa terdapat pengaruh yang kuat dalam proses belajar mengajar dengan menggunakan metode pembelajaran mnemonic di kelas X1 IPS 1 (kelas eksperimen), dibanding kelas X1 IPS 2 (kelas kontrol) yang tidak menggunakan metode pembelajaran mnemonic. Itu dikarenakan penerapan metode pembelajaran mnemonic lebih memberikan kesempatan pada siswa untuk belajar sendiri secara langsung menurut kemampuannya masing-masing.

\section{SIMPULAN DAN SARAN Simpulan}

Berdasarkan hasil penelitian, melalui analisis data dan pembahasan, bahwa terdapat pengaruh penerapan strategi pembelajaran mnemonic terhadap hasil belajar siswa pada mata pelajaran ekonomi di SMA Negeri 9 Palembang tahun pelajaran 2012/2013, hal ini dapat di lihat pada:

1. Rata-rata hasil belajar siswa pada kelas eksperimen yang dilakukan penerapan strategi pembelajaran mnemonic memperoleh nilai rata-rata 85,5 dengan kategori nilai "baik sekali" sedangkan pada kelas kontrol diperoleh nilai rata-rata sebesar 78,125 dengan kategori nilai "baik".

2. Hasil pengujian hipotesis menunjukkan bahwa ada pengaruh yang positif dari penerapan strategi pembelajaran 
mnemonic terhadap hasil belajar siswa pada mata pelajaran ekonomi di SMA Negeri 9 Palembang tahun pelajaran 2012/2013. Hal ini terlihat pada hasil pengujian hipotesis melalui perhitungan uji diperoleh $\mathrm{t}$ hitung $=9,41>\mathrm{t}_{\text {tabel }}=1,994$, maka $\mathrm{H}_{0}$ di tolak dan $\mathrm{H}_{\mathrm{a}}$ di terima.

3. Pengaruh penerapan strategi pembelajaran mnemonic terhadap hasil belajar siswa pada pengujian menunjukkan besar pengaruh sebesar 53,14\%, sedangkan selebihnya $46,86 \%$ dipengaruhi oleh faktor lain.

\section{Saran}

Berdasarkan dari hasil penelitian di atas, maka peneliti menyarankan:

a. Bagi siswa, diharapkan agar lebih aktif dan dapat menggunakan strategi belajar yang baik agar dapat memudahkan dalam mengingat materi pelajaran yang ada sehingga dapat meningkatkan hasil belajar.

b. Bagi guru, diharapkan dapat meningkatkan kualitas pembelajaran dengan menggunakan strategi pembelajaran mnemonic sebagai alternatif dalam mengajar guna menambah pengetahuan mengajar untuk masa yang akan datang.

c. Bagi sekolah, diharapkan dapat memberikan tambahan informasi mengenai strategi pembelajaran yang sesuai dengan kondisi kelas, sehingga akan lebih meningkatkan proses belajar mengajar di sekolah.

d. Bagi kalangan akademis, diharapkan dapat digunakan untuk bekal pengetahuan dan menambah pemahaman dalam usaha mempersiapkan diri sebagai pengajar atau melaksanakan penelitian selanjutnya.

\section{DAFTAR PUSTAKA}

Adji, Wahyu; Suwerli; dan Suratno. 2007. Ekonomi untuk SMA/MA Jilid 1. Jakarta: Erlangga.

Aqib, Zaenal dan Elham Rohmanto. 2008. Membangun Profesionalisme Guru dan Pengawas Sekolah. Bandung: Yrama Widya.

Arikunto, Suharsimi. 2010. Prosedur Penelitian Suatu Pendekatan Praktik. Jakarta: Rineka Cipta

Hamalik, Oemar. 2010. Proses Belajar Mengajar. Jakarta: Bumi Aksara.

http://akmalmr.blogspot.com/2011/03/strat egi-belajar-mnemonic.html diakses tanggal 25 April 2012

Marno dan M.Idris. 2009. Strategi dan Metode Pengajaran. Yogyakarta: Ar-Ruzz Media.

Mulyana, Enceng. 2008. Model Tukar Belajar (Learning Exchange). Bandung: Alfabeta. Munthe, Bermawy. 2009. Desain Pembelajaran. Yogyakarta: Pustaka Insan Madani. 
Nash, Yulianthe Kr. 2010. Kamus Super Lengkap Ekonomi SMA. Jakarta: Cyan Publisher.

Santrock, John W. 2010. Psikologi Pendidikan Edisi 2. Jakarta: Prenada Media Group.

Solso, Robert; Otto H. Maclin; dan M. Kimberly Maclin. 2007. Psikologi Kognitif. Jakarta: Erlangga.

Sudjana, Nana. 2009. Penilaian Hasil Proses Belajar Mengajar. Bandung: Remaja Rosdakarya.

Sugiyono. 2010. Statistik untuk Penelitian. Bandung: Alfabeta. 2012. Metode Penelitian Pendidikan (Pendekatan Kuantitatif, Kualitatif, dan $R \& D)$. Bandung: Alfabeta.

Tim Penyusun. 2012. Pedoman Penulis Skripsi, Palembang: Palembang: FKIP Universitas PGRI. 